\title{
PENGARUH FAKTOR MOTIVATOR DAN FAKTOR HIGIENE TERHADAP KEPUASAN KERJA KARYAWAN HOME INDUSTRY BATIK PASIR SEMERU DI PASIRIAN
}

\author{
Nicky Onidis \\ Department of Management FEB UMM \\ E-mail: nicky.onie@gmail.com
}

\begin{abstract}
The purpose of this study firstly, to know the motivation of the motivator factors and hygiene factors at home industry batik pasir semeru in pasirian, secondly to determine employee job satisfaction, thirdly to determine the influence of motivational factors and hygiene factors on employee job satisfaction, and fourthly to determine which factors most strongly influence employee job satisfaction. Based on the results of the calculation of the average scale range of motivator factors, hygiene factors and Employee Satisfaction included the company a high category.

From the calculation of the $F_{\text {test }}$ independent variables produced $F_{\text {tab }}=4,170877$ while the value of $F_{\text {hit }} 8,467$, t test motivator factors 2,587 and hygiene factors 2,877 while the value of $t_{\text {tab }} 2,04523$. Results of regression analysis equation model $Y=5,877+0,734 X_{1}+0,850 X_{2}+e$, the next coefficient of determination $\left(R^{2}\right)$ value is $36,9 \%$. It can be concluded that the motivator factors and hygiene factors variables significantly influence employee satisfaction.
\end{abstract}

Keywords: Factors Motivator, Factors Hygiene, Employee Satisfaction

\section{PENDAHULUAN}

Sukses sebuah organisasi tidak semata-mata hanya ditunjang oleh ketersediaan investasi dan aset yang dimilikinya karena dapat dipergunakan untuk pengadaan prasarana dan sarana serta teknologi yang menjadi pilihannya. Kemudahan untuk memperoleh bahan baku, membayar upah tenaga kerja yang dapat membantunya, tetapi yang utama adalah kualitas sumber daya manusia yang menjadi salah satu faktor produksi dalam kegiatan operasional bisnis ataupun industri.

Aspek sumber daya manusia mempunyai peranan penting dalam sebuah usaha, karena merupakan salah satu penentu keberhasilan suatu bisnis. Keberhasilan dan kemajuan suatu usaha tidak terlepas dari peran dan kemampuan sumber daya manusia yang baik. Penting untuk disadari oleh setiap pemilik usaha adanya cara untuk memberikan perhatian kepada para karyawan, dengan cara memberikan motivasi kepada karyawan agar dapat melaksanakan perintah sesuai aturan. Motivasi merupakan suatu dorongan yang dapat menggerakkan dan mempengaruhi karyawan agar melakukan tujuan tertentu. Pemilik usaha harus memberikan motivasi kepada karyawan dengan memenuhi harapan-harapan dari karyawan yang dirasakan sebagai kebutuhan mereka. Karyawan akan merasa puas dan termotivasi apabila perusahaan dapat memenuhi harapan mereka. 
Sebaliknya karyawan akan merasa tidak puas apabila harapan dan kebutuhannya tidak terpenuhi. Dengan adanya motivasi yang diberikan, karyawan akan lebih giat untuk bekerja. Dalam bekerja diperlukan adanya kerjasama antara pemimpin dan bawahan, sehingga terjalin hubungan yang harmonis dan tercipta koordinasi yang baik. Salah satu tugas yang harus dilakukan seorang pimpinan adalah meningkatkan kepuasan kerja karyawan dengan cara memotivasi karyawan.

Setiap karyawan menginginkan kepuasan dalam setiap pekerjaanya, karena kepuasan terbukti mempunyai manfaat yang besar bagi individu maupun perusahaan. Apabila karyawan merasakan kepuasan atau tidak puasan maka sikap dan tingkah laku dalam bekerja akan dapat dilihat, misalnya dari absensi, cara bekerja, dan lain-lain. Dengan demikian pemilik usaha dapat mengambil langkah-langkah yang tepat dalam memotivasi karyawan serta mencegah perilaku yang dapat merugikan perusahaan.

Penelitian ini difokuskan pada teori dua faktor Frederick Herzberg. Menurut Herzberg terdapat faktorfaktor yang dapat mempengaruhi motivasi yaitu faktor motivator dan faktor higiene. Faktor motivator adalah faktor-faktor atau situasi yang dibuktikannya sebagai sumber kepuasan kerja yang terdiri dari: prestasi, pengakuan, pekerjaan itu sendiri, tanggung jawab, pengembangan. Herzberg juga menyatakan bahwa para manajer dapat memotivasi individu dengan memasukkan motivator kedalam pekerjaan seorang individu agar dapat dicapai kepuasan.

Faktor higiene adalah faktorfaktor yang terbukti menjadi sumber ketidakpuasan yang terdiri dari: supervisi, kondisi kerja, hubungan antarpribadi, gaji atau upah, kebijakan perusahaan. Faktor higiene mempunyai hubungan dengan ketidakpuasan pekerjaan, karena faktor higiene ini bukan faktor pemuas tetapi faktor yang harus dipelihara dan harus dipenuhi oleh perusahaan. Oleh karena itu pemberian motivator dan higiene yang baik akan dapat meningkatkan kepuasan kerja karyawan.

Dalam proses memproduksi kain batik di home industry batik pasir semeru pemilik usaha juga memperhatikan cara kerja karyawannya agar kain batik yang dihasilkan sesuai dengan yang diharapkan tidak terdapat kesalahan dalam pembuatannya. Untuk dapat menghasilkan kain batik yang bagus pemilik usaha berusaha memberikan tambahan pengetahuan yang dimiliki ke para karyawan agar kualitas sumber daya manusianya semakin meningkat dan berdampak baik bagi keberlangsungan usaha.

Batik pasir semeru merupakan usaha home industry batik tulis yang berdiri sejak tahun 2010 dan memiliki karyawan berjumlah 32 orang, mereka bekerja untuk memenuhi kebutuhan hidup, usaha ini bergerak dalam bidang pembuatan kain batik tulis. Dalam proses pembuatan kain batik tulis di home industry batik pasir semeru ada 5 tahap pengerjaannya yaitu: desain motif pada kain, mencanting, mencolet warna, fiksasi, dan menghilangkan bekas malam pada kain (ngelorot). Dalam proses produksinya peranan 
karyawan sangat penting, karena karyawan yang mempunyai motivasi tinggi dalam bekerja dapat memberikan kepuasan kerja. Karyawan yang seperti ini akan bekerja dengan maksimal dan dapat menghasilkan produk kain batik yang berkualitas.

Dalam hal kepuasan kerja karyawan home industry batik pasir semeru ada permasalahan yang dihadapi yaitu adanya karyawan yang meninggalkan pekerjaanya karena merasa kurang nyaman dengan kondisi yang ada ditempat kerja selain itu juga berkaitan dengan hubungan rekan sekerja yang tidak harmonis, hal ini dapat membuat karyawan tidak puas dalam bekerja.

Kondisi yang terjadi pada home industry batik pasir semeru dapat berdampak pada motivasi karyawan dalam bekerja. Hal ini berkaitan dengan puas tidaknya karyawan dalam bekerja. Dengan demikian adanya hubungan timbal balik antara motivasi kerja karyawan dengan kepuasan kerja yang dirasakan karyawan. Adanya berbagai upaya yang dilakukan home industry batik pasir semeru seperti bentuk prestasi, pengakuan, pekerjaan itu sendiri, tanggung jawab, pengembangan, supervisi, kondisi kerja, hubungan baik antara karyawan dengan rekan sekerja ataupun dengan pemilik usaha, gaji atau upah serta kebijakan perusahaan dimaksudkan untuk meningkatkan motivasi karyawan dan membuat karyawan merasa puas.

\section{TINJAUAN PUSTAKA}

Berdasarkan penelitian terdahulu yang dilakukan oleh Junaidi (2000), dengan judul Pengaruh motivasi terhadap prestasi kerja karyawan bagian produksi pada perusahaan Keramik Pondowo malang, dengan hasil penelitian sebagai berikut:

Variabel yang diteliti adalah variabel bebas yaitu motivator $\left(\mathrm{X}_{1}\right)$, Higiene $\left(\mathrm{X}_{2}\right)$, sedangkan variabel terikat yaitu prestasi kerja karyawan (Y). alat analisis menggunakan regresi linier berganda. Hipotesis yang diajukan adalah diduga kedua variabel tersebut berpengaruh terhadap prestasi kerja karyawan dan juga faktor higiene berpengaruh paling dominan terhadap prestasi kerja karyawan.

Hasil analisis kedua variabel bebas tersebut menunjukkan adanya pengaruh terhadap prestasi kerja karyawan, sedangkan dari hasil analisis diperoleh persamaan regresi $\mathrm{X}_{1}=0,405$ dan $\mathrm{X}_{2}=0,583$, ini berarti hipotesis dapat dinyatakan bahwa faktor higiene berpengaruh dominan terhadap prestasi kerja karyawan.

Perbedaan penelitian terdahulu dengan penelitian sekarang adalah pada penelitian yang dilakukan oleh Junaidi mengambil lokasi di perusahaan keramik pendowo malang, sedangkan dalam penelitian ini mengambil lokasi di home industry batik pasir semeru. Variabel bebas yang digunakan adalah faktor motivator $\left(\mathrm{X}_{1}\right)$ dan faktor higiene $\left(\mathrm{X}_{2}\right)$ sedangkan dalam penelitian ini variabel terikatnya adalah kepuasan kerja (Y). Persamaan dari penelitian terdahulu dan penelitian sekarang adalah teori motivasi menurut Frederick Herzberg yaitu motivator dan higiene dan alat analisis yang digunakan analisis regresi linier berganda. 
Dengan demikian penelitian tersebut dapat dijadikan rujukan untuk mengadakan penelitian yang akan dilakukan, meskipun secara umum terdapat perbedaan. Disamping itu pada penelitian terdahulu motivasi dilihat pengaruhnya terhadap prestasi kerja, sedangkan pada penelitian sekarang dilihat pengaruhnya terhadap kepuasan kerja.

Menurut Moorhead dan Griffin (2013) motivasi adalah serangkaian kekuatan yang mengakibatkan orangorang berperilaku dengan cara tertentu. Sedangkan arti motif itu sendiri adalah daya pendorong atau tenaga pendorong yang mendorong manusia untuk bertindak atau suatu tenaga di dalam diri manusia yang menyebabkan manusia bertindak. Menurut Hasibuan (2002) motivasi adalah pemberian daya penggerak yang menciptakan kegairahan kerja seseorang agar mau bekerja sama, bekerja efektif dan terintegrasi dengan segala daya upaya untuk mencapai kepuasan. Motivasi adalah proses dimana usaha seseorang diberi energi, diarahkan, dan berkelanjutan menuju tercapainya suatu tujuan. (Robbins dan Coulter 2010)

Dari beberapa pengertian di atas maka dapat disimpulkan bahwa motivasi merupakan suatu penggerak yang dapat merangsang kerja karyawan yang mengarah kepada perilaku untuk mencapai kebutuhan yang diinginkan sehingga dapat tercapai tujuan yang telah ditentukan.

Teori motivasi dikelompokkan menjadi tiga kelompok menurut Bangun (2012) antara lain: teori isi, teori proses dan teori penguatan. Jenis-jenis motivasi dapat dikelompokkan menjadi dua jenis menurut Hasibuan (2003) yaitu: 1. Motivasi positif manajer memotivasi bawahan dengan memberikan hadiah kepada mereka yang berprestasi baik. Dengan motivasi positif ini semangat kerja bawahan akan meningkat, karena manusia pada umumnya senang menerima yang baik-baik saja. 2. Motivasi negatif manajer memotivasi bawahan dengan memberikan hukuman kepada mereka yang pekerjannya kurang baik (prestasi rendah). Dengan memotivasi negatif ini semangat kerja bawahan dalam waktu pendek akan meningkat, karena takut dihukum.

Pada dasarnya kepuasan kerja merupakan hal yang bersifat individual. Setiap individu akan memiliki tingkat kepuasan yang berbeda-beda sesuai dengan sistem nilai-nilai yang berlaku pada dirinya. Menurut Wexley dan Yukl (2003) dalam Bangun (2012) mengatakan bahwa kepuasan kerja merupakan generalisasi sikap-sikap terhadap pekerjaanya. Bangun (2012) kepuasan kerja adalah penilaian atas suatu pekerjaan apakah menyenangkan atau tidak menyenangkan untuk dikerjakan. Menurut Siagian (2002) menyatakan bahwa kepuasan kerja merupakan suatu cara pandang seseorang baik yang bersifat positif maupun yang bersifat negatif tentang pekerjaannya. Menurut Martoyo (2007) kepuasan kerja adalah keadaan emosional karyawan di mana terjadi ataupun tidak terjadi titik temu antara nilai balas jasa kerja karyawan dari perusahaan/organisasi dengan tingkat nilai balas jasa yang memang diinginkan oleh karyawan yang bersangkutan. Robbins (2006) kepuasan kerja adalah sikap lazim 
yang ditunjukkan seseorang terhadap pekerjaannya. Seseorang dengan kepuasan kerja yang tinggi memiliki sikap positif terhadap pekerjaannya. Seseorang yang tidak puas memiliki sikap negatif. Ketika orang-orang membicarakan sikap karyawan, mereka biasanya merujuk pada kepuasan kerja. Dari beberapa definisi diatas kepuasan kerja adalah sikap (positif) tenaga kerja terhadap pekerjaannya, yang timbul berdasarkan penilaian terhadap situasi kerja. Penilaian tersebut dapat dilakukan terhadap salah satu pekerjaannya, penilaian dilakukan sebagai rasa menghargai dalam mencapai salah satu nilai-nilai penting dalam pekerjaan.

Menurut Wexly dan Yukl dalam Bangun (2012) bahwa ada tiga teori tentang kepuasan kerja antara lain: 1. Teori Ketidaksesuaian. 2. Teori Keadilan. 3. Teori Dua Faktor. Faktor-faktor yang mempengaruhi kepuasan kerja menurut Robbins (2001): Kerja yang secara mental menantang, Ganjaran yang pantas, Kondisi kerja yang mendukung, Rekan sekerja yang mendukung, Kesesuaian antara kepribadianpekerjaan.

Menurut teori dua faktor Herzberg yang menjadi pokok bahasan dalam penelitian ini adalah faktor-faktor yang mempengaruhi kepuasan kerja seseorang dapat diuraikan sebagai berikut: 1. Faktor motivator atau intrinsik dihubungkan dengan kepuasan kerja, dimana motivator menyebabkan seseorang berpindah dari suatu keadaan tanpa kepuasan menjadi puas. 2. Faktor higiene atau ekstrinsik dimana faktor ini menyebabkan seseorang berpindah dari keadaan ketidak puasan menjadi tanpa ketidakpuasan, karena faktor ini bukan faktor pemuas tapi merupakan faktor pemeliharaan yang wajib diberikan kepada karyawan

Dalam suatu perusahaan motivasi sangat penting untuk diberikan, karena motivasi yang diberikan oleh perusahaan terhadap karyawan diharapkan akan dapat meningkatkan kepuasan kerja karyawan. Motivasi merupakan suatu penggerak atau dorongan yang dapat merangsang kerja karyawan yang mengarah pada perilaku kearah pencapaian tujuan kebutuhan yang diinginkan. Motivasi yang diberikan oleh perusahaan bertujuan untuk memberikan peluang bagi karyawan untuk berprestasi dan mengembangkan karir mereka. Karyawan yang termotivasi tertarik dalam menghasilkan produk tertentu, mereka cenderung lebih produktif dari pada karyawan yang tidak termotivasi.

Kepuasan kerja merupakan keadaan emosional yang menyenangkan atau tidak menyenangkan dalam diri karyawan yang berhubungan dengan pekerjaan dan kondisi karyawan. Kepuasan kerja merupakan hal yang bersifat individu, dan setiap individu memiliki tingkat kepuasan yang berbeda sesuai dengan dirinya.

\section{METODE PENELITIAN}

Lokasi penelitian dilakukan di home industry batik pasir semeru yang berada di Perumahan Pasirian Blok C-14. Alasan penulis memilih home industry batik pasir semeru sebagai objek penelitian dikarenakan adanya permasalahan terkait motivasi yang terdiri dari faktor motivator dan 
faktor higiene yang berpengaruh terhadap kepuasan kerja.

Jenis penelitian yang digunakan adalah survey. Penelitian survey digunakan untuk mendapatkan data dari tempat tertentu yang alamiah (bukan buatan), tetapi peneliti melakukan perlakuan dalam pengumpulan data misalnya dengan mengedarkan kuesioner, tes, wawancara terstruktur dan sebagainya, Sugiyono (2011).

Data yang digunakan adalah Data Primer dan Data Sekunder. Data primer adalah data yang diperoleh dari mengumpulkan data dari lokasi penelitian dimana objek berada dengan penyebaran kuesioner. Data primer diperoleh dan diolah sesuai dengan kebutuhan untuk analisis. Data sekunder adalah jenis data yang di ambil pada objek penelitian dengan data yang diperoleh sudah diolah oleh pihak lain atau dalam arti sudah dalam bentuk data gambaran umum perusahaan dan struktur organisasi yang ada.

Teknik Pengumpulan Data dalam penelitian ini adalah Wawancara dan Kuesioner. Sedangkan Populasi menurut Sugiyono (2011) adalah wilayah generalisasi yang terdiri atas obyek/subyek yang mempunyai kualitas dan karakteristik tertentu yang ditetapkan oleh peneliti untuk dipelajari dan kemudian ditarik kesimpulannya. Populasi dalam penelitian ini adalah seluruh karyawan home industri batik pasir semeru berjumlah 32 orang. Sugiyono (2011) menyatakan bahwa sampel adalah bagian dari jumlah dan karakteristik yang dimiliki oleh populasi tersebut. Menurut Arikunto (2002) teknik pengambilan sampel adalah subyeknya kurang dari 100 maka lebih baik di ambil semua sehingga merupakan penelitian populasi, selanjutnya jika subyeknya lebih dari 100 maka sampel yang diambil antara $10 \%-15 \%$ atau $20 \%$ $25 \%$ tergantung dari luas wilayah, dana, waktu, dan tenaga, karena jumlah populasi dalam penelitian ini 32 orang maka sampel yang digunakan adalah seluruh populasi yang ada, sehingga teknik sampel yang digunakan adalah total sampling.

\section{HASIL PENELITIAN DAN PEMBAHASAN}

Berdasarkan hasil perhitungan rentang skala dapat diketahui total skor pendapat responden tentang faktor motivator yang diukur dari prestasi yang ada di perusahaan $\left(\mathrm{X}_{1.1}\right)$, maka dapat diperoleh total skor 104 yang masuk dalam rentang skala 80-104 dengan kriteria tinggi. Dengan demikian dapat disimpulkan bahwa selama ini prestasi yang ada di perusahaan dapat membuat karyawan termotivasi. Berdasarkan hasil perhitungan rata-rata rentang skala diperoleh angka sebesar 102 yang berarti bahwa faktor motivator yang telah diberikan perusahaan selama ini masuk dalam kriteria tinggi.

Berdasarkan hasil perhitungan rentang skala dapat diketahui total skor pendapat responden tentang faktor higiene yang diukur dari supervisi yang telah dilakukan oleh perusahaan selama bekerja $\left(\mathrm{X}_{2.1}\right)$ diperoleh total skor sebesar 101 yang masuk dalam rentang skala 80-104 dengan kriteria tinggi. Dengan demikian dapat disimpulkan bahwa selama ini perusahaan dalam memberikan pengawasan baik kepada 
karyawan selama bekerja di perusahaan. Total skor pendapat responden tentang faktor higiene yang diukur dari kondisi atau situasi tempat kerja di perusahaan nyaman, aman dan menyenangkan $\left(\mathrm{X}_{2.2}\right)$ diperoleh total skor sebesar 86 yang masuk dalam rentang skala 80-104 dengan kriteria tinggi. Hasil tersebut membuktikan bahwa selama ini perusahaan berusaha menciptakan kondisi atau situasi tempat kerja di perusahaan nyaman, aman dan menyenangkan. Berdasarkan hasil perhitungan rata- rata rentang skala diperoleh angka sebesar 100,8 yanng berarti bahwa faktor higiene yang telah diberikan perusahaan selama ini dalam kriteria tinggi.

Berdasarkan hasil perhitungan rentang skala dapat diketahui skor pendapat responden tentang kepuasan kerja karyawan yang diukur dari sikap kepuasan karyawan atas prestasi yang telah dicapai selama bekerja di perusahaan $\left(\mathrm{Y}_{1.1}\right)$ diperoleh total skor sebesar 102 yang masuk dalam rentang skala 80-104 dengan kriteria tinggi. Hasil tersebut dapat membuktikan bahwa selama ini pihak perusahaan selalu berusaha memberikan kebebasan kepada karyawan untuk berprestasi selama bekerja di perusahaan. Total skor pendapat responden tentang kepuasan kerja karyawan diukur dari sikap kepuasan karyawan atas pengakuan dari perusahaan selama bekerja $\left(\mathrm{Y}_{1.2}\right)$ diperoleh total skor sebesar 100 yang masuk dalam rentang skala 80-104 dengan kriteria tinggi. Hasil tersebut dapat membuktikan bahwa selama ini pihak perusahaan memperhatikan keberadaan karyawan. Berdasarkan hasil perhitungan rentang skala diperoleh angka sebesar 99,1 yang berarti bahwa tingkat kepuasan kerja karyawan selama ini masuk dalam kriteria tinggi.

Hasil Analisis Regresi Linier BergandaAnalisis regresi linier berganda bertujuan untuk mengetahui gambaran hasil statistik mengenai pengaruh faktor motivator dan faktor higiene terhadap kepuasan kerja para karyawan home industry batik pasir semeru. Dalam melakukan pengolahan data dari hasil penyebaran kuesioner dengan program komputer melalui SPSS, adapun hasil analisis regresi linier berganda dapat dirumuskan suatu persamaan regresi berganda sebagai berikut:

$\mathrm{Y}=5,877+0,734 \mathrm{X}_{1}+0,850 \mathrm{X}_{2}+\mathrm{e}$ Dari persamaan garis linier berganda di atas, maka dapat diartikan bahwa: $\mathrm{Y}=$ Variabel terikat yang nilainya akan diprediksi oleh variabel bebas. Dalam penelitian ini yang menjadi variabel terikat kepuasan kerja para karyawan home industry batik pasir semeru yangg nilainya diprediksi oleh faktor motivator dan faktor higiene. a $=5,877$ merupakan nilai konstanta, yaitu estimasi dari kepuasan kerja karyawan home industry batik pasir semeru, hasil tersebut menunjukkan bahwa kepuasan kerja karyawan home industry batik pasir semeru yaitu sebesar 5,877. Hasil tersebut dapat membuktikan bahwa apabila home industry batik pasir semeru tidak memperhatikan faktor motivator dan faktor higiene maka kepuasan kerja karyawan sebesar 5,877. $\mathrm{b}_{1}=$ 0,734 merupakan slope atau koefisien arah faktor motivator yang mempengaruhi kepuasan kerja (Y) para karyawan home indutry batik pasir semeru. Koefisien regresi $b_{1}$ sebesar 0,734 dengan tanda positif. 
Berdasarkan hasil tersebut maka dapat disimpulkan bahwa apabila faktor motivator berubah naik dalam satu satuan maka kepuasan kerja karyawan akan naik sebesar 0,734 dengan asumsi faktor higiene mempunyai nilai sama dengan nol. Hasil tersebut dapat membuktikan bahwa apabila home industry batik pasir semeru memberikan adanya prestasi, pengakuan, pekerjaan itu sendiri, tanggung jawab, dan pengembangan, maka kepuasan kerja karyawan akan mengalami peningkatan sebesar $0,734 . b_{2}=0,850$ merupakan slope atau koefisien arah faktor higiene yang mempengaruhi kepuasan kerja karyawan home indutry batik pasir semeru. Koefisien regresi b2 sebesar 0,850 dengan tanda positif. Hasil tersebut maka dapat disimpulkan bahwa apabila faktor higiene berubah naik dalam satu satuan maka kepuasan kerja para karyawan home industry batik pasir semeru akan naik sebesar 0,850 dengan asumsi faktor motivator mempunyai nilai asumsi sama dengan nol. Hasil tersebut dapat membuktikan bahwa apabila perusahaan memperhatikan atau meningkatkan supervisi, kondisi kerja, hubungan antarpribadi, upah dan kebijakan perusahaan, maka kepuasan kerja karyawan akan mengalami peningkatan sebesar 0,850 .

Berdasarkan hasil analisis regresi linear berganda yang telah dilakukan menunjukkan pengaruh variabel independent dalam hal ini adalah faktor motivator dan faktor higiene terhadap variabel dependent yaitu kepuasan kerja para karyawan home industry batik pasir semeru adalah rendah. Dari hasil perhitungan analisis regresi linier berganda yang telah dilakukan menunjukkan pengaruh variabel independent terhadap variabel dependent adalah rendah. Hal tersebut dapat dilihat pada nilai koefisien determinasi $\left(\mathrm{R}^{2}\right)$ yaitu sebesar 0,369. Dengan demikian berarti bahwa kepuasan kerja karyawan home industry batik pasir semeru dipengaruhi oleh faktor motivator dan faktor higiene sebesar $36,9 \%$. Sedangkan sisanya $63,1 \%$ dipengaruhi oleh variabel-variabel lain yang tidak termasuk dalam penelitian ini. Hasil koefisien korelasi berganda menggambarkan kuatnya hubungan antara faktor motivator dan faktor higiene secara bersama-sama terhadap variabel kepuasan kerja para karyawan home industry batik pasir semeru adalah sebesar 0,607. Hal ini berarti hubungan antara keseluruhan variabel independen dan dependen adalah erat karena nilai $\mathrm{R}$ tersebut mendekati 1.

Berdasarkan hasil analisis regresi linier berganda maka diperoleh Ftab sebesar 4,170877 sdangkan $\mathrm{F}$ hit diperoleh nilai sebsar 8,467 sehingga dari perhitungan diatas dapat diketahui nilai $\mathrm{F}$ hit $>\mathrm{F}$ tab, berdasarkan hasil tersebut maka dapat disimpulkan bahwa faktor motivator dan faktor higiene secara bersama-sama mempunyai pengaruh signifikan terhadap kepuasan kerja karyawan home industry batik pasir semeru.

Berdasarkan perbandingan antara $t_{\text {hit }}$ dan $\mathrm{t}_{\mathrm{tab}}$ di atas menunjukkan bahwa faktor motivator dan faktor higiene mempunyai pengaruh yang signifikan terhadap kepuasan kerja para karyawan home industry batik pasir semeru. Hal tersebut karena $t_{\text {hit }}$ $>t_{\text {tab }}$ sehingga dari keseluruhan 
variabel yang digunakan dalam penelitian ini dapat menolak Ho.

Sedangkan dalam hal besarnya pengaruh masing-masing variabel secara keseluruhan dapat dilihat dari koefisien regresi masing-masing, yaitu faktor motivator $X_{1}$ yaitu sebesar 0,734 dan faktor higiene $\mathrm{X}_{2}$ sebesar 0,850. Jadi dengan demikian dapat disimpulkan bahwa faktor higiene mempunyai pengaruh yang lebih besar terhadap kepuasan kerja para karyawan home industry batik pasir semeru.

Berdasarkan hasil penelitian yang telah dilakukan menunjukkan bahwa faktor motivator karyawan yang terdiri dari prestasi termasuk tinggi ini disebabkan karena karyawan dapat berprestasi ditempat bekerja yaitu dapat menghasilkan hasil yang baik selama bekerja. Faktor motivator yang terdiri dari pengakuan termasuk tinggi ini disebabkan karena karyawan mendapatkan pengakuan dalam bekerja berupa pujian dan hal itu bisa membuat mereka merasa dihargai dalam pekerjaannya. Selain itu juga bisa membuat mereka lebih semangat dalam bekerja. Faktor motivator yang terdiri dari pekerjaan itu sendiri termasuk tinggi ini disebabkan karena karyawan merasa senang dengan pekerjaan yang dilakukan, dengan begitu mereka bekerja menggunakan hati dan akan dapat menghasilkan kain yang bagus. Faktor motivator yang terdiri dari tanggung jawab termasuk tinggi ini disebabkan karena karyawan dalam diberikan tanggung jawab sesuai dengan kemampuan yang mereka miliki, meski ada beberapa karyawan yang merasa terbebani karena kurang menguasai pekerjaannya. Faktor motivator yang terdiri dari pengembangan termasuk sangat tinggi ini disebabkan karena karyawan dalam bekerja mempunyai kesempatan untuk mengembangkan kemampuan yang mereka miliki sehingga mereka bisa berkembang.

Faktor higiene yang terdiri dari supervisi termasuk tinggi ini disebabkan karena karyawan dalam bekerja tidak merasa terlalu diawasi oleh atasannya sehingga selama bekerja karyawan bisa bebas tetapi tetap berada dalam ketentuan yang berlaku. Faktor higiene yang terdiri dari kondisi kerja termasuk tinggi ini disebabkan karena kondisi yang ada ditempat kerja bisa membuat karyawan merasa nyaman, meski ada beberapa karyawan yang merasa tempat bekerjannya kurang kondusif. Faktor higiene yang terdiri dari hubungan antarpribadi termasuk tinggi ini disebabkan karena hubungan dengan sesama ditempat bekerja dapat terjalin dengan baik, meski ada karyawan yang keluar dari tempat bekerja tetapi hal ini tidak mengurangi hubungan baik yang sudah terjalin sesama karyawan ditempat kerja. Faktor higiene yang terdiri dari gaji/upah termasuk sangat tinggi ini disebabkan karena upah yang diberikan perusahaan cukup untuk memenuhi kebutuhan karyawan dalam satu bulannya. Faktor higiene yang terdiri dari kebijakan perusahaan termasuk sangat tinggi ini disebabkan karena peraturan yang ada diperusahaan tidak memberatkan karyawannya sehingga karyawan bisa mematuhi peraturan yang sudah ditetapkan.

Kepuasan kerja yang terdiri dari sikap terhadap prestasi termasuk tinggi ini menunjukkan bahwa karyawan diberikan kesempatan 
untuk berprestasi dalam perusahaan. Kepuasan kerja yang terdiri dari sikap terhadap pengakuan termasuk tinggi ini menunjukkan bahwa karyawan dihargai dalam bekerja diperusahaan, sehingga pekerjaan yang mereka lakukan tidak sia-sia dan bisa memuat orang lain senang. Kepuasan kerja yang terdiri dari sikap terhadap pekerjaan itu sendiri termasuk tinggi ini menunjukkan bahwa karyawan merasa senang dengan pekerjaan yang mereka lakukan. Kepuasan kerja yang terdiri dari sikap terhadap tanggung jawab termasuk tinggi ini menunjukkan bahwa pekerjaan yang diberikan tidak membebankan karyawan dalam bekerja. Kepuasan kerja yang terdiri dari sikap terhadap pengembangan termasuk sangat tinggi ini menunjukkan bahwa karyawan mempunyai kesempatan untuk dapat mengembangkan kemampuannya dalam bekerja diperusahaan. Kepuasan kerja yang terdiri dari sikap terhadap supervisi termasuk tinggi ini menunjukkan bahwa pengawasan yang dilakukan perusahaan tidak mengganggu keberadaan karyawan dalam perusahaan selama mereka bekerja. Kepuasan kerja yang terdiri dari sikap terhadap kondisi kerja termasuk tinggi ini menunjukkan bahwa kondisi yang ada diperusahaan dapat mendukung mereka dalam menyelesaikan pekerjaannya.

Kepuasan kerja yang terdiri dari sikap tehadap hubungan antarpribadi termasuk tinggi ini menunjukkan bahwa sesama karyawan dapat menjalin hubungan dalam bekerja diperusahaan. Kepuasan kerja yang terdiri dari sikap terhadap gaji/upah termasuk tinggi ini menunjukkan bahwa perusahaan dalam memberikan upah kepada karyawan cukup untuk memenuhi kebutuhannya. Kepuasan kerja yang terdiri dari sikap terhadap kebijakan perusahaan termasuk tinggi ini menunjukkan bahwa kebijakan yang ditetapkan perusahaan menjadi pedoman yang jelas bagi karyawan dalam bekerja diperusahaan.

Berdasarkan hasil pengujian secara simultan terbukti bahwa faktor motivator dan faktor higiene secara bersama-sama berpengaruh signifikan terhadap kepuasan kerja karyawan. Hasil tersebut dapat memberikan gambaran bagi pihak perusahaan bahwa faktor motivator dan faktor higiene perlu mendapatkan perhatian secara serius dalam usaha meningkatkan kepuasan kerja karyawan. Dari hasil uji secara parsial menunjukkan bahwa faktor motivator berpengaruh signifikan terhadap kepuasan kerja karyawan. Berdasarkan pengaruh masingmasing faktor menujukkan bahwa faktor higiene berpengaruh dominan terhadap kepuasan kerja karyawan.

Hasil penelitian ini sesuai dengan teori yang menyatakan bahwa kepuasan kerja adalah generalisasi sikap-sikap terhadap pekerjaannya (Bangun, 2012). Menurut herzberg faktor-faktor yang mempengaruhi kepuasan kerja seseorang dapat diuraikan sebagai berikut: 1. Faktor motivator atau intrinsik dihubungkan dengan kepuasan kerja, dimana motivator menyebabkan seseorang berpindah dari suatu keadaan tanpa kepuasan menjadi puas. 2. Faktor higiene atau ekstrinsik dimana faktor ini menyebabkan seseorang berpindah dari keadaan ketidakpuasan menjadi tanpa ketidakpuasan, karena faktor ini 
bukan faktor pemuas tapi merupakan faktor pemeliharaan yang wajib diberikan kepada karyawan.

Hasil tersebut juga didukung atau dapat dikaitkan dengan karakteristik responden yang sebagian besar adalah belum menikah, tingkat pendidikan terakhir adalah SMA dan lama bekerja diperusahaan 3-4 tahun. Kondisi tersebut menjadikan seorang karyawan akan berusaha secara maksimal dapat memperoleh kesempatan yang telah diberikan perusahaan kepada karyawan. Misalnya apabila ditinjau dari besarnya upah yang diberikan maka karakteristik responden tersebut terkait erat dengan tingkat pendidikan dan sebagian besar karyawan adalah belum menikah. Hasil penelitian ini mendukung penelitian terdahulu yang dilakukan oleh junaidi (2000), yang menyatakan bahwa faktor higiene memiliki pengaruh yang lebih besar dibandingkan faktor motivator terhadap kepuasan kerja karyawan.

\section{SIMPULAN}

Berdasarkan hasil penelitian dan pembahasan yang telah dilakukan maka dapat ditarik kesimpulan bahwa berdasarkan hasil perhitungan ratarata rentang skala faktor motivator diperoleh angka sebesar 102 yang berarti bahwa faktor motivator yang telah diberikan perusahaan selama ini masuk dalam kriteria tinggi. Sedangkan hasil perhitungan rata-rata rentang skala faktor higiene diperoleh angka sebesar 100,8 yang berarti bahwa faktor higiene yang telah diberikan perusahaan selama ini masuk dalam kriteria tinggi. Hasil perhitungan rentang skala kepuasan kerja karyawan diperoleh angka sebesar 99,1 yang berarti bahwa kepuasan kerja karyawan selama ini masuk dalam kriteria tinggi. Berdasarkan hasil analisis regresi linier berganda dapt disimpulkan bahwa faktor motivator $\mathrm{X}_{1}$ dan faktor higiene $\mathrm{X}_{2}$ secara bersama-sama mempunyai pengaruh yang signifikan terhadap kepuasan para karyawan home industri batik pasir semeru. Berdasarkan hasil koefisien regresi terbukti bahwa faktor higiene mempunyai pengaruh yang lebih besar terhadap kepuasan para karyawan home industri batik pasir semeru apabila dibandingkan dengan faktor motivator.

\section{DAFTAR PUSTAKA}

Arikunto, Suharsimi. 2010. Prosedur Penelitian. Jakarta: Rineka Cipta.

Bangun, Wilson. 2012. Manajemen Sumber Daya Manusia. Jakarta: Erlangga.

Hasibuan, Malayu. 2002. Manajemen Sumber Daya Manusia, Edisi Revisi. Jakarta: Bumi Aksara.

Hasibuan, Malayu. 2003. Organisasi dan Motivasi Dasar Peningkatan Produktivitas, Cetakan Ketiga. Jakarta: Bumi Aksara.

Martoyo, Susilo. 2007. Manajemen Sumber Daya Manusia Edisi Kelima. Yogyakarta: BPFE Yogyakarta.

Moorhead, Gregory dan Griffin, Ricky W. 2013. Perilaku Organisasi Manajemen Sumber Daya Manusia dan Organisasi. Jakarta: Salemba Empat.

Robbins, Stephen P. 2001. Perilaku Organisasi Konsep Kontroversi Aplikasi, Edisi Kedelapan. Jakarta: PT Prenhallindo. 
Robbins, Stephen P. 2006. Perilaku

Perilaku Organisasi

Organisasi: Konsep,

Kontroversi, Aplikasi. Jakarta:

PT Prenhallindo.

Robbins, Stephen P dan Coulter, Mary. 2010. Manajemen, Edisi Kesepuluh. Jakarta: Erlangga.

Siagian, Sondang. 2002. Manajemen Sumber Daya Manusia. Jakarta: Bumi Aksara.

Sigit, Soehardi. 2003. Esensi

Edisi 2003.

Yogyakarta: BPFE UST.

Sugiyono. 2011. Metode Penelitian Kuantitatif Kualitatif dan $R \& D$. Bandung: CV Alfabeta. Umar, Husain. 2001. Riset Sumber Daya Manusia Dalam Organisasi Edisi Revisi. Jakarta: PT Gramedia Pustaka Utama. 